\title{
INNOVATIVE BLOCKCHAIN TECHNOLOGY AS A FACTOR OF ECONOMIC DEVELOPMENT
}

\section{CHEBERYAKO OKSANA}

Doctor of Habil. in Historical Sciences, PhD in Economics, Professor, Taras Shevchenko National University of Kyiv, Ukraine, cheberyako@ukr.net

\section{NIKYTENKO DMYTRO}

Doctor of Habil. in Economics, Professor,

National University of Water and Environmental Engineering, Ukraine

d.v.nikytenko@nuwm.edu.ua

\section{VARNALII ZAKHARII}

Doctor of Habil. in Economics, Professor,

Taras Shevchenko National University of Kyiv, Ukraine

vzs1955@gmail.com

\section{KOLESNYK VIKTOR}

Doctor of Habil. in Historical Sciences, Professor,

Taras Shevchenko National University of Kyiv, Ukraine

kolesnykvf@ukr.net

\section{BORYSENKO OLEKSANDRA}

PhD in Philology, Associate Professor of

the Department of Foreign Languages, The Faculty of Economics,

Taras Shevchenko National University of Kyiv, Ukraine

o.borysenkotsu@gmail.com

Abstract. In the era of digitalization of the world economy, the main resource is comprehensive, reliable, truthful and upto-date information. The field of the information technology has become a producer of innovations that are beginning to be widely used outside their industry. The research paper considers the innovative blockchain technology, which has been tested in the financial sector using cryptocurrency. Its scope is not limited to the financial sector, it creates social networks, online voting systems, various applications for supply chain control, and etc. Generally, this technology is becoming a factor in the transformation of relations 'state-business', 'business-business', 'population-state', as well as a modern factor of economic development at all hierarchical levels of the economy. The main task of blockchain technology was to ensure trust in society that eliminates confidence by default, as trust is a necessary, but not sufficient, institutional factor for the development at the different levels of the economic system. The paper presents the areas of application of blockchain technologies, most of which were previously under the strict centralized state control, the advantages and disadvantages of this technology were identified.

Blockchain technology is being considered from two sides: in terms of its ability to ensure efficiency and productivity at different levels of the national economy (efficiency function) and as an institutional technology - an innovative form of economic coordination that will be an alternative to established conservative forms. The paper shows the practical application of blockchain technology in Ukraine and prospects for its development.

KEYWORDS: BLOCKCHAIN TECHNOLOGY, DIGITALIZATION, DIGITAL ECONOMY, INNOVATIVE DECISIONS, USE OF BLOCKCHAIN, FINANCIAL OPERATIONS, FINANCIAL SPHERE, INVESTMENTS, ECONOMIC DEVELOPMENT.

For citation: Cheberyako O., Nikytenko D., Varnalii Z., Kolesnyk V., Borysenko O. (2021) Innovative blockchain technology as a factor of economic development, Globalization and Business, №11, 11-15. https://doi.org/10.35945/gb.2021.11.001 


\section{INTRODUCTION}

The onset of the globalization process caused by the COVID-19 pandemic has led to increase competition between countries for economic development factors, including foreign direct investment, until the window of opportunity closes. The formation of a modern structure of the economy due to the intensification of technology transfer and renovation is not possible without the use of modern technological solutions and technical means. One of the most important technologies today become blockchain technology. Expanding the scope of its application will be able to increase the level of attractiveness of Ukraine among foreign investors, because in this essence, blockchain technology is characterized by transparency, the ability to reduce transaction costs and is associated with trust. No wonder 'The Economist' in 2015 called blockchain technology a "trustmachine". (The Economist, 2015).

Blockchain technology is actively tested in the financial sector on the basis of cryptocurrencies, but is not limited only this. Based on this technology, social networks, online voting systems, various applications for supply chain control, etc. are created. In addition, this technology can be a factor in the transformation of relations "state-business", "business-business", "population-state". In other words, the main transformation will be related to the possibility of delegating to a computer program (algorithm) for conducting and certifying transactions without the participation of third parties (state, banks, other intermediaries), the results of which will be trusted by all or the most economic entities (market). According to F. Fukuyama and due to the sociological research in different countries of the world there is a steady decline in the confidence in the main traditional social institutions (Fukuyama, 2004). The main objective of blockchain technology was to create trust in the environment, which eliminates such expectation by default, since trust is a necessary, but not sufficient, institutional factor for development at different levels of the economic system.

The introduction of blockchain technology in the economy is widely discussed among politicians, economists, lawyers, experts in the field of information and telecommunications technology, public administration.The study of blockchain technology in recent years has been devoted to the work of such scholars and practitioners as D. Tapscott, A. Tapscott (Tapscott \&Tapscott, 2016), G.W. Peters, E. Panayi (Peters \&Panayi,2016), M. Swan (Swan, 2015), Z. Zheng, S. Xie, H. Daiand, H. Wang (Zheng, Xie, Dai \& Wang, (2016), J. Yli-Huumo, D. Ko, S. Choi, S Park, K. Smolander (Yli-Huumo, Ko, Choi, Park \& Smolander, 2016) and other researchers and professionals. At the same time, the dynamics of the development of innovative technologies requires their constant monitoring, implementation and effective application as a factor of economic development in the era of Industry 4.0.

The aim of the article is to study the world experience of the blockchain technology application in various spheres of the economy and to determine the potential of its use in the economy of Ukraine.

In addition to the financial sector in terms of cryptocur- rency, blockchain technology is beginning to be used in many different areas at the micro and macro levels of the national economy. Peculiarities of this technology are: decentralized data storage, immutability (impossibility of substitution) of data, security, the presence of a consensus algorithm for synchronization of distributed data. All these peculiarities of blockchain technology are formalized in so-called smart contracts, which provide speed, accuracy, trust, security and economy.

As noted by Berg and others (Berg, ..., (2018), blockchain technology can fundamentally change the way in which socio-economic interactions are coordinated by decentralizing those processes that involve public registries. If the State, through authorized institutions, now centrally establishes sets of rules governing our social and economic interactions, in the future it can be hoped that blockchain as an alternative form of keeping registers, can ensure transparency and auditing in electronic voting and in governance in general. In general, at the macro level, blockchain technology can be seen on the one hand as an innovative general-purpose technology that is undergoing its introduction into the economy, as are other technologies such as computers or the Internet. On the other hand, blockchain technology can be considered as an institutional technology (Davidson,..., 2018), which creates a new form of coordination of economic actions of groups of people. As noted by other scholars (Markey Towler, 2018), from this point of view, the blockchain is not just a technology, but a new type of economy that allows you to create "autonomous organizations" with constitutional market and governmental properties. This is, in any case, a challenge for Governments in the evolution of society.

Blockchain technology is actively developing and will attract the significant investment. Its areas of application may be: financial (digital asset markets, off-market financial transactions, anti-fraud transaction tracking), governance (corporate, public, especially agrarian, property rights protection) security (in terms of proof of identity), medical field. This technology can also be applied to electronic auctions, the electoral process, humanitarian and social services and micromanagement. (Varnalii, ...,2019)

Initially, the scope of blockchain technology was the banking system. This was determined by the fact that the decentralized data register was viewed solely as a technology for economic and non-monetary work in banking transactions. The operation of the blockchain in this area is justified by the effectiveness of its application to interbank transfers, securities movements, databases of insurance histories and escrow accounts. Thus, the European Banking Organization has recognized that the blockchain will improve the market for banking services and will be able to reduce the fee for transactions, as well as improve the transaction speed processing and increase profits.The use of blockchain technology in other areas will minimize or completely avoid corruption markers as well as the human factor in individual decision-making.

Despite the fact that blockchain technology is mainly related to the field of finance, the scope of this technology is not limited. Along with banks and Fintech startups, players in other non-financial markets have also turned their attention 
to the technology and are looking for the ways to capitalize on the opportunities it provides. This will lead to the fact that some industries in the national economy will be radically restructured. Decentralization will change the business logic of many companies and services, and therefore not all companies will be able to stay. As can be seen from the application of blockchain technology, many companies are exploring the possibility of applying it outside the financial sphere. According to the Organization for Economic Cooperation and Development, about $10 \%$ of world GDP will be generated through the direct use of blockchain technology. The main benefits of technology deployment are expected in the form of reduced transaction costs, settlement time, minimized risks and additional profit opportunities. (R3CEVLLC).

As to the geographical features of blockchain technology, it is worth noting that the higher a country is ranked in the Economic Freedom Index, the more common this technology is. Among such countries are Australia, Canada and the United States.

Australia has pioneered global blockchain standardization by chairing the International Organization for Blockchain's technical committee. In addition, as the third freest country in the world in 2021 (The Heritage ..., 2021) on the basis of respect for the rule of law, the size of government intervention in the economy, the effectiveness of regulation and the level of open markets, the Australian Government publishes numerous reports, explore the potential of blockchain.

The high level of economic freedom, the presence of a reliable free market determines the opportunities for business development and growth of its level of innovation. This, in turn, provides a favorable environment for the development of blockchain technology.

The main areas of blockchain technology application are the financial sector and logistics (supply chain management). However, according to a survey of respondents, public land registries and registration of property rights are among the desired and therefore potential applications of such technology, identity and passport documentation, and health records management. (Beck, ..., 2019:150).

The Heritage Foundation (2021) is one of the top 10 freest countries in the world, and aims to provide an enabling environment for the use of new technologies and innovations, particularly as a blockchain. Public-private partnerships are manifested in the collaboration of The National Research Council, the Canadas Industrial Research Assistance Program with a number of organizations, including ColliderX, The Blockchain Association of Canada, Blockchain Research Institute and others to develop a nationwide blockchain ecosystem. (Beck, ..., 2019:155).

Traditionally, the financial area has been the focus of the implementation of blockchain technology, but among its potential applications are the administration, arbitration and auditing functions. Canada has a fairly well-developed scientific infrastructure for blockchain technology research. Thus, in Toronto, Don and Alex Tapscott, after the publication of their work on the revolutionary nature of the blockchain (Tapscott \&Tapscott, 2016), founded the Blockchain Research Institute. They identified 10 sectors that are interested in blockchain technology: energy, financial services, management, health, manufacturing, media, retail, mining, technology and telecommunications. In addition to examining the impact of blockchain on industry sectors, they are also exploring how micro-level blockchain can change corporate governance in the areas of strategy and leadership, and supply chain development, formation of reasonable contracts and legal programs, management of corporate finances, formation of architecture of enterprise, management of human resources, as well as marketing and advertising. (Blockchain ..., 2019).

In general, Canada has many initiatives to promote innovation and blockchain technology, and research in this area is evolving, especially through the Blockchain Research Institute.

In the case of China, despite being ranked 107 in the economic freedom index (The Heritage ..., 2017), it can now be considered one of the leading countries in terms of the use of blockchain technology and not only because of the extremely high level of cryptocurrency activity as a mining activity, and trade, and therefore that half of the world's cryptocurrency transactions originate from China, compared to $25 \%$ from the US and $15 \%$ from the EU. Moreover, China is by far the largest holder of patents on blockchain technology, and the largest patent-holding organization is the Central Bank of China. China's active participation in international standardization groups, such as the International Organization for Standardization (ISO), demonstrates its strategic interest in blockchain technology.

The Chinese Government was promoting the development of the blockchain industry at the national level, which meant that provinces and cities would follow suit with financial support programs and favorable conditions. As a result, the People's Bank of China has more blockchain patents than any other organization in the world; Chinese corporations such as Alibaba and JD.com rush to develop and implement blockchain solutions, and startups such as NEO, develop standard blockchain solutions that are applied various sectors and spheres of business.

The Chinese government is investing heavily in both blockchain initiatives and commercial benefits for startups in selected industries. Today, China is widely regarded as a leading blockchain country due to the intensity, depth and breadth of its activities in all parts of Chinese society.

Estonia has a reputation as one of the leading countries in digitalization. Blockchain technology has been tested since 2008 and, as of 2012, the Government of Estonia has already used blockchain technology in various registers in areas such as the national health system, the judiciary and legislation (e-government, e-voting), security and commercial code.

Given the size of the country and the economy, the focus is on the information and computer technology, the financial and insurance industries, while the public sector is the main sector in Estonia that influences blockchain. The Estonian government has a reputation for being digitally advanced. Unlike other countries, it was the Estonian Government that was more motivated to introduce blockchain solutions than the private sector. 
The European Union as a whole has established itself as a key player in the promotion and regulation of blockchain technology. The creation of the European Blockchain Partnership (EBP) and cooperation in the creation of the European Blockchain Services Infrastructure (EBSI) will promote cross-border digital public services with the highest standards of security and confidentiality. The fundamental transformation of economic coordination forms can be seen in the EU and in the measures taken to institutionalize blockchain technology. So blockchain becomes a technology that can change the institutional architecture of governance not only of the state, but also of the totality of states.

In the case of Ukraine, the low protection of property rights, raiding and opportunistic behavior of counterparties in business processes is an inexhaustible list of threats to the efficient functioning and active investment of economic entities. The risks associated with periodic change of ownership, the struggle for control of assets, are most significant, especially for foreign investors, who are very sensitive to the security of their business. Therefore, they consider Ukraine as a high-risk country for investment, and the economy itself is characterized by low competitive advantages in attracting foreign investment and investment activities.The introduction of blockchain technologies in public administration and the public sector will ensure the inviolability of the rule of law and thereby increasing the level of confidence in the relevant public institutions, as well as becoming a powerful tool in the fight against corruption.

In Ukraine, the use of blockchain was actively started in the last few years, and Ukraine itself became one of the 14 leading countries in the introduction of technology in 2017. (R3CEVLLC). According to the Blockchain Association of Ukraine, in 2017, 32\% of all companies that use this technology were founded. The fields of application of blockchain technology are traditional for the initial stage of development: programming and development (38\%); finance, investment and trading (38\%); cryptography and cryptocurrency (32\%); and marketing and advertising (12\%).

Bitfury. In April 2017, the State Agency for E-Government of Ukraine and Bitfury signed a memorandum of cooperation in the field of blockchain technologies. The project involves the transfer of all government data stored electronically to the blockchain platform. It is planned to transfer to a new system of State registers, social services, security, health care and energy services of Ukraine. As a result, it will allow to control all changes that occur with state assets, improve the protection of state databases from unauthorized interfer- ence, reduce costs for citizens, attract investment in Ukraine and reduce corruption in all areas.

AtticLab is a Ukrainian fintech startup that specializes in creating innovative software products using blockchain technology. Among the most famous products of the company: CODEX and AtticLabEOSBlockProducer.

Bloqly is a Ukrainian blockchain startup founded in 2018 and develops a new blockchain platform for use by businesses and governments to create reusable decision blocks. The main areas of application - in education, finance, road transport, agriculture and security.

In early June 2017, the first blockchain auction was held, which allows to rent out state property (R3CEVLLC). In September 2017, SETAM was the first in the world to transfer its base to blockchain, and in October 2018 began to transfer to blockchain the State land cadaster. Every transaction in the cadaster is a blockchain. It is not public; four nodes are in the Ministry and one node auditor - in Transparency International (it allows to see changes in the system). To prevent hacking of all nodes and attempts to change the data, information from the blockchain is cached into the Bitcoin blockchain as the most reliable data storage. The general idea is that as the integration of technology deepens, citizens will be able to obtain their "keys", without which no one will be able to make changes to the record of their sites.

An open platform for e-democracy. In August 2016, the E-Vox team agreed to install a voting system in the Balta City Hall (Odessa region), and deputies were able to vote directly from smartphones, leaving a corresponding entry in the blockchain. Two banks in Ukraine (OschadBank and PrivatBank) are already building an infrastructure for working with electronic money based on blockchain technology. The concept of the e-government portal on the blockchain - E-Ukraine - was presented by the Blockchain Conference Kiev in March 2016.

Thus, blockchain technology and its wide application can become a tool for stimulating the development of an open information society, a factor for increasing productivity, economic development and job creation. This institutional and technological innovation is not a panacea for shortcomings in public governance, but a way of making information more secure. At this stage, technology does not solve the main problems of the country, but it creates the conditions for increasing the level of trust, which today there is a great need of citizens and the world community. Blockchain technology will have a real impact as it deepens its integration into various spheres of social life.

\section{REFERENCES:}

Beck, R., Kubach, M., Jørgensen, K. P., Sellung, R., Schunck, C., \&Gentile, L. (2019). STUDY ON THE ECONOMIC IMPACT OF BLOCKCHAIN ON THE DANISH INDUSTRY AND LABOR MARKET. IT-Universitetet i København. IT University Technical Report Series Vol. 2019. No. 206.

Berg, C., Markey-Towler, B., Novak, M. \&Potts, J., (2018). Blockchains Evolving: Institutional and Evolutionary Economics Perspectives. (Online) Availableat: https://doi.org/10.2139/ssrn.3160428

Blockchain Research Institute, 2019. Blockchain Research Institute: FAQ. (Online) Availableat: https://www. blockchainresearchinstitute.org/faq/ 
Davidson, S., De Filippi, P. \& Potts, J., (2018). Blockchains and the economic institutions of capitalism. Journal of Institutional Economics, 14 (https://doi.org/10.1017/S1744137417000200), :639-658.

Fukuyama, F. (2004). Trust. Social virtues and way to prosperity.

Klymenko, I., Lozova, G., Akimova, L. (2017). Application of blockchain technologies in public administration. Academic papers collection. 2017. Issue 20. URL: http://dv.Ivivacademy.com/article/view/151029/150053.

Markey-Towler, B., (2018). Anarchy, Blockchain andUtopia: A Theory of Political-Socioeconomic Systems Organisedusing Blockchain. (Online) Availableat: https://papers.ssrn.com/sol3/papers.cfm?abstract_id=3095343

Peters, G. \& Panayi, E. (2016). Understanding modern banking ledgers through blockchain technologies: Future of transaction processing and smart contracts on the internet of money. Banking Beyond Banksand Money. URL: (PDF) arxiv.org.

R3CEVLLC (Електронний ресурc). - URL: https://www.r3.com (Date 04.04.2018). - Screen name.

Swan, M. (2015). Blockchain Blueprintfor a New Economy. O’Reilly Media Final Release Date. 2015. January:22.; Свон, Мелані. Блокчейн: Схема новой экономики / Мелани Свон : (пер. с англ.). - Москва: Изд. «Олимп-Бизнес»,:2017-240., іл. (текст рос. мовою). Режим доступа: https://kniga.biz.ua/pdf/5351-Blockchain.pdf.

Tapscott, D. \&Tapscott A. (2016). Blockchain revolution: How the Technology Behind Bitcoin is Changing Money, Business, and the World. URL : http://dontapscott.com/books/blockchain-revolution.

The Economist. 2015. "The Trust Machine." October 31. URL: https://www.economist.com/news/leaders/21677198technology-behind-bitcoincould-transform-how-economy-works-trust-machine.

The Heritage foundation, 2021. 2021 Index of EconomicFreedom. (Online) Available at: https://www.heritage.org/index/ ranking

Varnalii, Z., Cheberyako, O., Nikytenko, D., Bilyk, R. (2019). Blockchain Technologyas a Security Tool and a Factor of Trust to Information in the Digital Economy. International Journal of Recent Technology and Engineering (IJRTE), Vol. 8, Issue 3C, November 2019:207-212. DOI:10.35940/ijrte.C1035.1183C19

Yli-Huumo J. Ko D., Choi S., Park S., \&Smolander K. (2016). Where is current research on blockchain technology? - a systematic review. PloSone. URL: journals.plos.org.

Zheng, S. XieH.N. Dai\&Wang H., (2016). Blockchain challenges and opportunities: A survey. WorkPap.-2016. URL: henrylab. net. 